Revista Destaques Acadêmicos, Lajeado, v. 9, n. 2, 2017. ISSN 2176-3070 DOI: http://dx.doi.org/10.22410/issn.2176-3070.v9i2a2017.1400 www.univates.br/revistas

\title{
A VIOLAÇÃO DOS DIREITOS DE PERSONALIDADE DE VÍTIMAS DE ACIDENTES DE TRÂNSITO PELA EXPOSIÇÃO DE IMAGENS
}

\author{
Sabrina Schmitt ${ }^{1}$, Beatris Francisca Chemin ${ }^{2}$
}

Resumo: O desenvolvimento da tecnologia ensejou o surgimento de novas ferramentas de comunicação, as quais proporcionaram inúmeras facilidades para o convívio social. No entanto, a utilização descontrolada de alguns desses instrumentos vem causando invasões na esfera individual das pessoas, que sofrem com exposições indevidas de sua imagem, honra e privacidade. Assim, este artigo acadêmico tem como objetivo analisar a ocorrência da violação dos direitos de personalidade de vítimas de acidentes de trânsito, que têm sua imagem exibida nos mais diversos espaços de comunicação, como jornais, redes sociais e aplicativos na internet. Trata-se de pesquisa qualitativa, realizada por meio de método dedutivo e de procedimento técnico bibliográfico e documental. Dessa forma, a primeira seção versa sobre a descrição dos direitos de personalidade, previstos na Constituição Federal como direitos fundamentais. Em seguida, faz reflexões sobre os direitos à liberdade de expressão e de informação. Finalmente, examina a exposição de imagens de acidentados, situação que pode gerar colisão de direitos fundamentais entre o direito à informação e os direitos de personalidade. Nesse sentido, conclui que os casos de exposição de imagens de vítimas de acidentes de trânsito devem ser interpretados por intermédio da aplicação do princípio da ponderação, o qual leva em consideração principalmente as circunstâncias particulares do exercício de cada caso. Em vista disso, ainda não há entendimento unânime quanto à questão, mas se compreende que ocorre a violação dos direitos de personalidade quando a imagem veiculada se revestir de sensacionalismo, de exageros, os quais são desnecessários à comunicação da ocorrência do acidente.

Palavras-chave: Direitos de personalidade. Direito à liberdade de expressão e de informação. Imagens de vítimas de acidentes de trânsito. Colisão de direitos fundamentais.

1 Bacharela em Direito pela Univates. Advogada. sabrinaschimitt@hotmail.com

2 Professora do Curso de Direito da Univates. Mestre em Direito. bchemin@univates.br 


\section{INTRODUÇÃO}

A evolução da tecnologia faz com que a difusão da informação se torne cada vez mais imediata e abrangente. A internet trouxe muitas mudanças à organização social e às relações interpessoais. A rapidez na circulação de informações tem imensurável importância no convívio diário. Especialmente por intermédio de aplicativos e das redes sociais, os indivíduos são constantemente atualizados sobre os mais diversos acontecimentos. Entretanto, a facilidade de qualquer um registrar imagens e expô-las nas redes sociais, acreditando na ideia de não haver uma limitação legal, vem causando confrontos na esfera judicial.

Nessa linha, é cada vez mais frequente a exposição de imagens de vítimas de acidentes de trânsito. Embora para algumas pessoas essas cenas violentas e brutais sejam apenas mais um post a ser compartilhado, não se pode olvidar das consequências que tal divulgação enseja no mundo jurídico.

Ainda que a divulgação de imagens envolvendo acidentados tenha o condão de conscientizar as pessoas sobre as consequências trazidas pelas imprudências no trânsito e encontre respaldo legal na liberdade de informação e expressão, é essencial que ela não invada o campo dos direitos de personalidade da vítima para violar sua imagem, honra e intimidade.

Assim, este artigo tem o objetivo de analisar situações em que a exposição de imagens de vítimas de acidentes de trânsito viola os direitos de personalidade por exceder os limites da liberdade de expressão e de informação, delineando a sua ocorrência, as consequências e possível viabilidade de reparação. O estudo propõe como problema: em que circunstâncias são violados os direitos de personalidade de vítimas em acidentes de trânsito pela exposição de suas imagens? Acerca da hipótese para tal indagação, entende-se que o direito à imagem é um dos elementos constitutivos dos direitos da personalidade, elevados pela Constituição Federal ao grau de direitos fundamentais. A exposição de imagens encontra limites nas garantias da inviolabilidade da intimidade, da vida privada e da honra. Por outro lado, a liberdade de expressão e da atividade intelectual, artística, científica e de informação também é consagrada como um direito fundamental. Portanto, o ato de expor e compartilhar imagens de vítimas de acidentes de trânsito gera uma colisão entre os direitos de personalidade e a liberdade de expressão e de informação, sendo que quando um passa a preponderar sobre o outro, gerando excessos e arbítrios, é necessário buscar uma solução técnica pautada na ponderação de normas.

A pesquisa, com relação à abordagem, adotará o modelo qualitativo, uma vez que o caráter subjetivo da abordagem do tema inviabiliza a exata mensuração prática e estatística dos dados, conforme Mezzaroba e Monteiro (2014), e utilizará o método dedutivo, cuja operacionalização se desenvolverá por meio de procedimentos técnicos baseados na doutrina, legislação e 
jurisprudência, focados inicialmente aos direitos de personalidade, passando pelo direito à liberdade de expressão e informação, a fim de chegar ao caso particular da exposição de imagens de vítimas de acidentes de trânsito.

Assim, a violação dos direitos de personalidade pela exposição de imagens de vítimas de acidentes de trânsito é uma questão pertinente a ser desenvolvida, principalmente por ser um tema atual e polêmico, presente nas relações de convivência de muitos dos brasileiros, especialmente daqueles que registram, recebem e compartilham essas imagens, muitas vezes, sem conhecer as implicações legais que isso pode acarretar.

\section{DIREITOS DE PERSONALIDADE}

O surgimento de uma nova concepção de dignidade da pessoa humana no fim do século $\mathrm{XX}$ e a necessidade de proteger os valores a ela inerentes ensejaram a personalização do direito, que até então era especialmente patrimonial.

Inicialmente, os direitos de personalidade surgiram como um conceito proposto para despertar o sentimento humano, visando a suprimir os massacres étnicos da Segunda Guerra Mundial. Devido a sua importância, passaram a ser convertidos em preceitos e inseridos no ordenamento jurídico (PEREIRA, 2016). No Brasil, em função da dignidade da pessoa humana ter sido consagrada pela Constituição Federal de 1988 (CF/1988) como princípio fundamental e a inclusão dos direitos de personalidade no Código Civil de 2002 (CC), cada vez mais frequente é a invocação desses direitos como ferramentas para solução de litígios.

Em vista disso é que esta seção terá como objetivo descrever noções sobre a conceituação dos direitos de personalidade, sua previsão legal, características, classificações, bem como o direito à imagem, à honra e à privacidade e suas limitações.

\subsection{Conceituação, previsão legal e características dos direitos de personalidade}

Primeiramente, convém mencionar o significado da palavra personalidade, que é apontada por Telles Jr. apud Diniz (2007, p. 117) como o "conjunto de caracteres próprios da pessoa". Destaca Fiuza (2014) que esse conjunto de atributos, compostos pela vida, a honra e o corpo físico são o objeto dos direitos de personalidade.

Para Bittar (2015, p. 34), os direitos de personalidade, são considerados como "poderes que o homem exerce sobre a própria pessoa". Na visão de Gagliano e Pamplona Filho (2016), os direitos de personalidade possuem como objeto as características físicas, psíquicas e morais da pessoa em si e em suas projeções sociais. Para eles, tratam-se de direitos extrapatrimoniais do indivíduo, abrangendo valores não mensuráveis pecuniariamente, como a vida, 
a integridade física, a intimidade, a honra, entre outros. Indica Gonçalves (2016) que esses direitos têm a incumbência de resguardar os decorrentes do princípio que se encontra em primeiro plano entre os fundamentos constitucionais - a dignidade humana.

A CF/1988 elenca de forma expressa os direitos de personalidade consagrando-os como fundamentais em seu art. $5^{\circ}$, inc. $X$, ao afirmar que "são invioláveis a intimidade, a vida privada, a honra e a imagem das pessoas, assegurado o direito a indenização pelo dano material ou moral decorrente de sua violação"; o inc. XLI confere uma tutela genérica, prescrevendo que "a lei punirá qualquer discriminação atentatória dos direitos e liberdades fundamentais"; inc. V assegura "o direito de resposta, proporcional ao agravo, além da indenização por dano material ou moral à imagem". No Código Civil, foram elencados no art. 11 ao 21.

Na visão de Amaral (2000, p. 248), são direitos personalíssimos que se "caracterizam por serem essenciais, inatos e permanentes, no sentido de que, sem eles, não se configura a personalidade, nascendo com a pessoa e acompanhando-a por toda a sua existência".

\subsection{Direito à imagem, à honra e à privacidade}

Várias são as construções doutrinárias acerca da divisão dos direitos de personalidade em classes. Gagliano e Pamplona Filho (2016), Amaral (2000) e Bittar (2015) segmentam os direitos de personalidade em proteção à vida, integridade física (corpo, cadáver, voz), integridade psíquica (liberdade) e integridade moral (honra, imagem, identidade pessoal), asseverando que essa listagem não pode ser considerada taxativa, em vista da constante evolução dos valores essenciais do ser humano.

Diante disso, nota-se que esses direitos são perceptíveis sob duas formas: uma guarda relação com a pessoa em si (suas particularidades e características próprias), e a outra à sua posição frente aos outros na coletividade.

A honra, a imagem e a privacidade estão elencadas na categoria dos direitos morais pelos escritores acima citados, e por serem o objeto principal deste texto, serão melhor aprofundados em seguida:

a) o direito à imagem: partindo do pressuposto de que cada pessoa tem características externas próprias que a diferenciam e individualizam das demais no meio social, Bittar (2015) e Diniz (2007) consideram o direito à imagem como o elo do ser humano à sua expressão na sociedade, não podendo ser mercantilizada sem seu consentimento;

b) direito à honra: também inserido no âmbito dos direitos de personalidade, esse direito é conceituado como "[...] a dignidade pessoal e a consideração que a pessoa desfruta no meio em que vive. É o conjunto de predicados que lhe conferem consideração social e estima própria. É a boa reputação" (AMARAL, 2000, p. 264); 
c) direito à privacidade: encontra proteção jurídica no art. 21 do CC referindo que a vida privada da pessoa natural é inviolável. Esse dispositivo, em consonância com o art. $5^{\circ}, \mathrm{X}$ da CF/1988, destinase à proteção das pessoas de atentados indevidos no seu ambiente reservado e íntimo, como o lar, família e economia (GONÇALVES, 2016).

De modo geral, destinam-se os direitos de personalidade a proteger a dignidade humana, por meio de sanções que podem ser pleiteadas pelo ofendido, conforme prevê o art. 12 e par. único, CC. Em havendo lesão, a vítima poderá ingressar com pedido judicial para que cessem as ameaças, podendo pleitear ainda indenização por dano moral ou patrimonial. Insta salientar que $o$ art. 943, CC possibilita que os herdeiros do ofendido morto também reclamem o dano patrimonial ou moral.

\section{DIREITO À LIBERDADE DE EXPRESSÃO E À INFORMAÇÃO}

A informação é considerada uma das principais necessidades do homem na sociedade atual. Ela foi e será pressuposto de sobrevivência, visto que vital para enfrentar as circunstâncias concretas da comunidade onde se vive e se atua. Protegida pela CF/1988 como direito fundamental, o direito à informação é composto de duas liberdades no âmbito jurídico. Abordase o direito à liberdade de expressão no art. $5^{\circ}$, IV, bem como a liberdade de informação ou comunicação no art. $5^{\circ}$, IX e XIV. Desse modo, esta seção terá como objetivo identificar os aspectos fundamentais da liberdade de expressão e de informação, estabelecendo seu contexto histórico, finalidade e limitações.

\subsection{Liberdade de expressão}

Um dos elementos constitutivos do direito à informação é a liberdade de expressão. Analisando o sentido semântico da palavra 'expressão', ela significa "o ato ou efeito de exprimir a manifestação de um sentimento" (FERREIRA, 2009 , p. 858). Essa conceituação guarda relação com o âmbito jurídico, no qual a liberdade de expressão é vista como sendo a faculdade que o cidadão dispõe de expressar livremente seus pensamentos, ideias e ideais (MARQUES, 2010).

A Carta Magna de 1988 contém múltiplos dispositivos relacionados à liberdade de expressão, destacando-se o art. $5^{\circ}$, IV e V. Canotilho et al. (2014) entendem que é fundamental compreender que o modelo de liberdade de expressão afirmado pela CF/1988 é, portanto, o da liberdade com responsabilidade, evitando a forma abusiva no exercício de seu direito, visando ao resguardo do direito de terceiros. Outrossim, considerando que na Internet é comum as pessoas emitirem opiniões e comentários pejorativos sobre os outros, acreditando estarem amparadas pela liberdade de expressão, alertam que, mesmo sendo ambiente virtual, é considerado um local público, 
estando também sujeito a restrições, e deve-se tomar o cuidado de exercê-la com responsabilidade.

Menciona Rodrigues Júnior (2009, p. 60) que a liberdade de expressão "abrange qualquer exteriorização da vida própria das pessoas: crenças, conviç̧ões, ideias, ideologias, opiniões, sentimentos, emoções e atos de vontade". Nesse sentido, a linguagem simbólica também é admitida, visto que há condutas que possuem natureza predominantemente expressiva, pois possuem como objetivo principal a transmissão de uma mensagem.

Em virtude do plano subjetivo, Farias (2004) enfatiza que a liberdade de expressão não está limitada e submetida ao controle da verdade. Diferentemente disso, tem-se o entendimento de que a liberdade de informação, por ser constituída de elementos objetivos, está vinculada à comprovação da verdade.

\subsection{Liberdade de informação}

Etimologicamente, a palavra 'informação' significa "o conjunto de condições e modalidades de difusão para o público (ou colocada à disposição do público) sob formas apropriadas de notícias ou elementos de conhecimento, ideias ou opiniões" (TERROU apud SILVA, 2007, p. 245).

A CF/1988 tutelou a liberdade de informação em seu art. $5^{\circ}$, IX e XIV, assegurando o direito de projetar e receber informações das mais variadas espécies: "IX- é livre a expressão da atividade intelectual, artística, científica e de comunicação, independentemente de censura ou licença; [...] XIV- é assegurado a todos o acesso à informação e resguardado o sigilo da fonte, quando necessário ao exercício profissional". Aliado a esses dispositivos, o art. 220 reconhece que a manifestação da informação pode se dar de qualquer forma, processo ou veículo, sendo proibido qualquer tipo de censura.

Ainda que intrinsicamente ligados na prática, no âmbito jurídico o direito à liberdade de expressão não se confunde com a liberdade de informação. Enquanto a liberdade de expressão significa a manifestação de uma opinião ou ideia, a liberdade de informação está ligada com a difusão de fatos ou notícias, e por possuir conteúdo objetivo fica suscetível à comprovação da verdade (FARIAS, 2004).

Em 2009, os Ministros do Supremo Tribunal Federal julgaram procedente a Arguição de Descumprimento de Preceito Fundamental (ADPF n. 130) e declararam a inconstitucionalidade da Lei de Imprensa (Lei 5.250/1967), sob o argumento de que é necessário proteger primeiramente a livre e plena manifestação da informação, para então cobrar do ofensor eventual violação a outro preceito constitucional. Como consequência, a categoria das limitações dos meios de comunicação ficou potencialmente ilimitado. Este também é um problema que acomete a Internet, considerada um dos meios mais utilizados para a manifestação de ideias, notícias e imagens da atualidade. 
Ainda que em 2014 tenha sido sancionada a Lei 12.965, conhecida como Marco Civil da Internet, que estabeleceu princípios e deveres para a utilização da Internet, críticas têm sido formuladas, dentre elas a insuficiência de inovações práticas no âmbito jurídico. Também, devido à inviabilidade de unificação da rede mundial de computadores, é notório que as ameaças aos direitos de personalidade permanecem (TOMASEVICIUS FILHO, 2016). Embora haja a presença de distinções teóricas entre o direito à liberdade de expressão e o direito à liberdade de informação, na prática a sua relação não é simples. Assim, segundo Rodrigues Júnior (2009), não existe nenhuma diferença substancial entre eles, visto que é tarefa difícil tratar esses institutos de maneira isolada, afinal a expressão se apoia na narração de fatos e a comunicação de notícias também não se dá em um estado puro, contendo algum elemento valorativo, demonstrando, assim, a sua interligação. Em função disso, é que os limites que serão analisados, bem como quando no decorrer deste texto for feita menção a esses institutos, considerar-se-ão como aplicáveis tanto à liberdade de expressão quanto à liberdade de informação.

\subsection{Limites à liberdade de expressão e de informação}

A possibilidade de imposição de limites à liberdade de expressão e de informação é um tema que suscita constante discussão legislativa. Tanto é que o Ministro Carlos Brito, ao proferir seu voto no julgamento da ADPF 130, anteriormente explanada, sustentou que não poderia ser imposto qualquer limite legal em relação às liberdades em questão, se não àquelas já existentes no texto constitucional.

Sob ponto de vista diverso, no julgamento do RE 511.961/SP, o Ministro Gilmar Mendes defendeu que as restrições à liberdade de expressão e informação em sede legal são possíveis quando tenham a finalidade de promover outros valores e interesses relevantes.

Assim, ainda que integrantes do quadro dos direitos fundamentais, não há como afirmar que a liberdade de expressão e informação estejam livres de parâmetros para o seu exercício.

Rodrigues Júnior (2009) traça as fronteiras da liberdade de expressão em duas grandes categorias: as limitações absolutas e relativas. Na primeira, estariam inseridos limites intransponíveis, que independem de previsão legal para sua aplicação, como o respeito à vida e ao princípio da dignidade da pessoa humana; na segunda esfera, encontram-se limitações que não possuem caráter absoluto, sendo positivadas no ordenamento jurídico, como, por exemplo, o respeito à honra, à imagem e à privacidade. Assim, a seguir, explana-se cada uma:

a) Limitações absolutas da liberdade de expressão e informação: essas limitações, também conceituadas como restrições tácitas, possuem fundamento constitucional e justificam-se principalmente 
pelo caráter prima facie dos direitos e liberdades consagrados na Constituição; assim, por serem considerados como princípios supraconstitucionais, sua obediência é implícita (FARIAS,2004). Dentre os limites considerados absolutos, destacam-se o direito à vida e a dignidade da pessoa humana;

b) Limitações relativas: dizem respeito especialmente às previsões legais, que limitam ou restringem o exercício da liberdade de expressão e informação (RODRIGUES JÚNIOR, 2009).

A CF/1988 coíbe, em seu art. 220, a restrição à manifestação de pensamento, da criação, da liberdade de expressão e da informação, preservando, porém, a inviolabilidade do direito à intimidade, à vida privada, à honra e à imagem das pessoas. Em suma, nesse contexto, há de se respeitar principalmente os direitos de personalidade.

Similarmente, quanto ao amparo à honra, o elemento condicionante para estabelecer os limites da liberdade de expressão é o interesse social. Assim, quando se trata de fatos úteis, de interesse coletivo, há prevalência deste sobre o direito individual à honra. No entanto, é vedada a divulgação de fatos sensacionalistas, que apenas servem para aumentar audiência, satisfazendo o público, pois afetam a reputação de uma pessoa (RODRIGUES JÚNIOR, 2009).

Por fim, no tocante ao direito de imagem, igualmente tem-se como regra geral o interesse público sobre a imagem. Portanto, são admitidas fotografias coletivas, realizada com a intenção de informar as pessoas sobre uma questão de ordem pública; no entanto, não se enquadram nessa situação, conforme o autor, "[...] a publicação de foto ou filmagem de alguém para ilustrar determinada reportagem, pois esta tem a finalidade comercial e muitas vezes o conteúdo da matéria não é condizente com o entendimento da pessoa fotografada ou filmada" (RODRIGUES JÚNIOR, 2009, p. 129).

O que se pretende, portanto, sob pena de gerar uma colisão de direitos, é equilibrar o exercício da liberdade de expressão e informação com os demais direitos. Assim, na próxima seção, passar-se-á a examinar a ocorrência da violação dos direitos de personalidade de vítimas de acidentes de trânsito pela exposição de imagens.

\section{VIOLAÇÃO DOS DIREITOS DE VÍTIMAS DE ACIDENTES DE TRÂNSITO}

Ainda que sejam inúmeros os benefícios trazidos pelos avanços tecnológicos, especialmente os ligados à Internet, a celeridade e a facilidade na difusão de imagens e informações impossibilitam, muitas vezes, a realização de uma filtragem prévia do que está sendo exposto e compartilhado nas redes. Consequentemente, imagens das mais variadas formas, captadas em diferentes situações, acabam sendo frequentemente compartilhadas pelos usuários e 
também utilizadas pelos meios de comunicação. Nesse âmbito, destaca-se a crescente exposição de imagens de vítimas de acidentes de trânsito.

No entanto, não se pode olvidar que tal exposição enseja consequências no mundo jurídico, especialmente quando ultrapassar os limites do exercício da liberdade de expressão e de informação e passar a entrar no campo destinado aos direitos de personalidade, podendo, assim, ocasionar a violação da honra, da imagem e da privacidade das pessoas, cujas circunstâncias serão a seguir estudadas.

\subsection{Ocorrência da violação dos direitos de personalidade}

Os atentados contra os direitos de personalidade vêm crescendo diariamente, sendo que Bittar (2015) atribui como principal causa a isso o avanço das técnicas de comunicação. Para Schreiber (2013b), além dos avanços nos meios utilizados para captação de imagens, o fácil acesso à Internet permite a difusão das imagens de maneira descontrolada; livres de qualquer controle prévio de seu conteúdo, vídeos e imagens são lançados livremente e até mesmo anonimamente nas redes, o que torna o seu rastreamento tarefa extremamente difícil, fazendo com que, muitas vezes, a violação à imagem seja irreversível.

Salienta Pereira (2016) que toda pessoa tem a faculdade de proteger a sua imagem e impedir sua divulgação, tanto é que a lei veda a divulgação de imagens independentemente do meio utilizado, seja fotografia, seja vídeo. Nessa ótica, compreende que o atentado contra a imagem pode ocorrer com a simples divulgação de uma fotografia em condições que diminuam ou ridicularizam a pessoa, ou apenas partes do seu corpo.

Nessa lógica, Pinheiro e Sleiman (2009) sugerem que se deve ter muito cuidado com as fotos exibidas em $b$ logs e comunidades, bem como evitar o envio de fotos e vídeos por celular para outras pessoas, tendo em vista que nesses momentos, devido à euforia, não se consideram as possíveis consequências.

Igualmente, alerta Paesani (2003, p. 48) que as informações referentes à vida privada somente podem ser consideradas lícitas "quando justificadas por um legítimo interesse do sujeito que as recebe; trata-se de saber se o fim a que a informação serve tem mais valor que o interesse do sujeito ao qual se refere essa informação".

Semelhante é o entendimento de Schreiber (2014, p. 28) ao tecer considerações sobre a exposição de imagens:

[...] a veiculação televisiva da mesma imagem, retratando a dor e a comoção de certa pessoa envolvida em evento trágico, pode ser considerada lícita quando destinada a informar o público acerca do acontecimento, mas tida como ilícita ou abusiva quando tem por finalidade divulgar, a título de publicidade, a eficiência do próprio canal de televisão na colheita da notícia. 
Cavalieri Filho (2007) argumenta que quando a imagem de uma pessoa estiver sendo utilizada em sentido amplo e genérico, demonstrando que a finalidade principal não é a exploração econômica nem a identificação da pessoa, mas sim apenas noticiar algum acontecimento, não há violação ao direito de imagem. Assim, fazendo-se uma interpretação do disposto pelo doutrinador e aplicando tal premissa ao caso prático de imagens de acidentes de trânsito, entende-se que quando a notícia ou a publicação restringir-se ao ato de informar sobre a ocorrência do acidente não haverá violação à imagem ou à honra. Caso contrário, quando a informação se utiliza de imagens que exponham o corpo da vítima em situação debilitada ocorre a violação dos direitos de personalidade da vítima, visto que tal imagem mostra-se desnecessária ao caráter informativo da publicação.

Nesse patamar, Schreiber (2014) defende que uma imagem, que inicialmente possa ter sido utilizada de forma legítima com a liberdade de informação, pode ter sua veiculação vedada se surgirem novas circunstâncias fáticas, fazendo, assim, prevalecer o direito à imagem.

Considerando a relevância da imagem no campo dos direitos de personalidade, bem como as constantes ameaças a esse direito na atualidade, preleciona Schreiber (2013a) que o desafio real deste milênio é a proteção da imagem, tendo em vista a flagrante insuficiência de valores dos cidadãos frente às novas tecnologias, que tornaram extremamente vulneráveis a imagem, a privacidade e a intimidade.

Inobstante seja uníssono no âmbito doutrinário o reconhecimento da violação dos direitos relacionados à personalidade quando ocorre a divulgação de imagens de pessoas envolvidas em situações trágicas, a jurisprudência ainda não possui entendimento pacificado quando tratar-se de exposição de vítimas de acidentes de trânsito. Assim, nesses casos, alguns Tribunais consideram que a publicação de vídeos e imagens em jornais ou sites da internet não afrontam os direitos de personalidade quando seu conteúdo se restringir ao ato de informar e alertar sobre a ocorrência do acidente e não possuir intenção sensacionalista:

APELAÇÃO CÍVEL. Ação indenizatória. Reportagem veiculada em site de notícia. Fotografia do autor após ter sofrido acidente de trânsito. Liberdade de informar. Dever de indenizar inexistente. Conforme cediço a liberdade de informação assegurada pelo artigo 220 da CF/88 não é absoluta, encontrando óbice nos direitos fundamentais constitucionais de imagem e intimidade, quando comprovado abuso do dever de informar. Hipótese em que a parte autora não logrou demonstrar qualquer excesso por parte das requeridas, as quais agiram com a devida observância ao interesse público ao veicular notícia e fotografia dando conta de acidente de trânsito ocorrido na ERS 142, limitando-se a informar o fato ocorrido. Além disso, conforme entendimento sedimentado nesta Corte, a publicação inconsentida da imagem sem o fim econômico, de per 
si, não gera a obrigação de indenizar, cabendo a parte demonstrar o efetivo dano a sua honra. Prejuízo não demonstrado. Sentença de improcedência mantida. Apelação desprovida. (Apelação Cível n ${ }^{\circ}$ 70065581381 - RS, Tribunal de Justiça do Rio Grande do Sul, Relator: Des. Paulo Roberto Lessa Franz. Julgado em 30 jul. 2015).

Similar é a interpretação quando por intermédio da imagem publicada não for possível reconhecer a identidade da vítima ou que a reportagem não seja ofensiva:

RECURSO INOMINADO. Ação de indenização por danos morais. Veiculação de vídeo na mídia do momento do acidente que teve como vítima fatal a irmã da autora. Reportagem jornalística que não se mostra ofensiva, falsa ou pejorativa. Danos morais que não restaram configurados. 1. No conteúdo das reportagens e vídeo do momento do acidente publicado pela parte ré, não se verifica nenhuma ofensa à honra ou imagem da pessoa falecida, tratandose de conteúdo meramente informativo, sem nenhum caráter sensacionalista e pessoal. 2. No tocante ao vídeo propriamente dito, o acidente divulgado, embora possa parecer trágico e desagradável para a autora que é irmã da falecida, conforme salientou o juiz de origem 'tem-se que este, em suas imagens, não possui clareza e tampouco nitidez, sendo que a imagem da mídia não é capaz de retratar a fisionomia da pessoa atropelada, nem tampouco de demonstrar o estado do corpo após a ocorrência da colisão fatal'. Sentença de improcedência mantida. Recurso desprovido (Recurso Cível n 71005951777 - RS, Tribunal de Justiça do Rio Grande do Sul, Relatora: Glaucia Dipp Dreher. Julgado em 01 abr. 2016).

Sob outro patamar, há julgados que reconhecem que a exposição dessas imagens trágicas causa abuso do direito de expressão e de informação, ocasionando, assim, a violação aos direitos de personalidade, especialmente o direito de imagem:

APELAÇÃO CÍVEL. Ação de indenização. Reportagem jornalística. Dano moral. Destaque, em contracapa de jornal, do corpo de vítima fatal de acidente automobilístico, filho dos autores. Publicação que ultrapassa o objetivo de prestar informação. Abuso de direito. Abalo moral. Dever de indenizar. A experiência cotidiana revela que os acidentes de trânsito são fatos de interesse público, corriqueiramente noticiados pela mídia jornalística. Certamente, este interesse não deve se pautar pela curiosidade sensacionalista, mas pela conveniência de se informar o que ocorre nas vias brasileiras, possibilitando aos cidadãos e ao governo a adoção de respostas preventivas para diminuir o risco da violência nas estradas. No caso, o interesse público certamente não exige a imagem do cadáver da vítima, mas recai sobre a boa informação e descrição do 
acidente, como ele realmente ocorreu. Fixação da indenização em patamar razoável. Inversão dos ônus sucumbenciais. Adequação dos honorários advocatícios ao art. 20 do CPC. Sentença reformada. Recurso conhecido e provido. (Apelação Cível n ${ }^{\circ}$ 2007.053376-8 - SC, Tribunal de Justiça de Santa Catarina, Relator: Des. Victor Ferreira. Julgado em 05 maio 2011).

Cabe ressaltar que em 2013, a então deputada federal Aline Corrêa propôs o Projeto de Lei 5.012/13, o qual alterava a redação atual do art. 20 do CC, incluindo: "§ $2^{\circ}$ Ao lidar com vítima fatal de acidente ou de crime, a autoridade competente zelará pela preservação de sua dignidade, evitando sua exposição pública, bem como o uso indevido de sua imagem", o qual foi arquivado em 30/01/2015, pela Mesa Diretora da Câmara dos Deputados, em função do encerramento da legislatura da autora da proposição.

Portanto, verifica-se não há entendimento uniforme sobre a ocorrência da violação dos direitos de personalidade de vítimas de acidentes de trânsito, visto que esse é um típico caso de colisão de direitos fundamentais, travada entre os direitos de personalidade e o direito à informação, cuja solução não se dá exclusivamente pela simples interpretação normativa, gerando, em função disso, interpretações distintas e muitas vezes contraditórias.

\subsection{Colisão entre os direitos de personalidade e o direito à informação}

Os direitos de personalidade e o direito à informação colidem, porque vão além do plano abstrato, afinal a finalidade do direito é aplicar normas válidas em casos concretos. Dessa forma, “[...] as normas de direito fundamental se mostram abertas e móveis quando de sua realização ou concretização na vida social. Onde há um catálogo de direitos fundamentais constitucionalizado, há colisões in concreto" (STEINMETZ, 2001, p. 63).

Destarte, frequentemente, no exercício do direito de informar, ocorrem confrontos com os direitos de personalidade, ocasionados pela veiculação de informações que invadem a esfera íntima da pessoa humana e violam sua honra, imagem e privacidade (GODOY, 2001). A colisão dos direitos de personalidade com a liberdade de informação significa que opiniões e fatos ligados à honra, imagem e intimidade não podem ser divulgados ao público indiscriminadamente. Todavia, a liberdade de informação, considerada como essencial para o funcionamento da sociedade democrática, também não deve ser restringida a ponto que resulte em inutilidade (FARIAS, 1996).

Exemplo prático da colisão dos direitos de personalidade e o direito à liberdade de expressão e de informação é a exposição de imagens de vítimas de acidentes de trânsito. Em consonância a jurisprudência:

AGRAVO DE INSTRUMENTO. Direito Constitucional. Ação Civil Pública. Direito difuso. Liberdade de imprensa. Limites. Exposição 
em jornais impressos de fotografias e imagens em destaques de pessoas vítimas de acidentes, assassinadas e demais mortes brutais. Violação da intimidade, da honra e da imagem. Infringência à dignidade da pessoa humana. Desrespeito aos mortos. Colisão entre direitos fundamentais. Inteligência do art. $5^{\circ}, \mathrm{IV}, \mathrm{V}, \mathrm{IX}, \mathrm{X}, \mathrm{XII}$ E XIV c/c o art. 220, 10, da Carta Magna. Aplicação do princípio da proporcionalidade. Imposição de obrigação de não fazer. Multa diária. Recurso conhecido e parcialmente provido. [...]. II - In casu, há aparente conflito de direitos fundamentais, quais sejam o de livre manifestação e o da inviolabilidade da esfera íntima (art. $5^{\circ}$, $X$ da $C F)$, quando, no foco, encontra-se a liberdade de imprensa. Se, por um lado, é garantido aos meios de comunicação noticiar acontecimentos e expressar opiniões, por outro, não podemos olvidar o direito dos cidadãos à inviolabilidade da intimidade, da honra e da imagem. [...]. V. Recurso conhecido e parcialmente provido para impor às empresas agravadas a obrigação de não fazer representada pela proibição imediata da utilização, nos jornais de suas responsabilidades, de fotos/imagens de pessoas vítimas de acidentes e/ou mortes brutais e demais imagens que não se coadunem com a preservação da dignidade da pessoa humana e do respeito aos mortos, evitando-se, com isso, a utilização de imagens chocantes e brutais, sem qualquer conteúdo jornalístico, mas com intuito meramente comercial. (Agravo de Instrumento $\mathrm{n}^{\circ}$ 200830118631 - PA, Tribunal de Justiça do Pará, Relator: Des. Eliana R. D. Abufaiad. Julgado em: 06 abr. 2009). (Grifo das autoras)

Devido ao princípio da unidade da Constituição, é inviável a interpretação isolada de cada dispositivo. Assim, procuram-se buscar meios que permitam a compatibilização adequada do direito à informação com os direitos de personalidade (CANOTILHO et al., 2014). Na prática, as colisões de direitos fundamentais são avaliadas como casos difíceis e duvidosos. Steinmetz (2001) os caracteriza desse modo porque o que colidem são direitos fundamentais constitucionalizados com idêntica valoração hierárquica e vinculante, sendo, portanto, necessária uma decisão legislativa ou judicial que equilibre o contido na Constituição com a realidade enfrentada. Segundo Alexy apud Andréa (2013), muito já se escreveu e ainda permanece sendo tema de várias interpretações por parte da doutrina estrangeira e nacional, tendo em vista que, devido à importância do assunto na atualidade, cada vez mais tem-se buscado apontar critérios que sirvam de base para uma possível solução. Sendo assim, apontam-se alguns parâmetros utilizados para a ponderação entre os direitos de personalidade e a liberdade de expressão e informação.

\subsection{Critérios de solução}

Como visto e conforme mencionam Canotilho et al. (2014), a colisão de direitos fundamentais é um fenômeno rotineiro no constitucionalismo brasileiro. Assim, é tarefa do intérprete jurídico a criação do Direito aplicável 
ao caso concreto, tendo como pressuposto as balizas de cada norma. Acrescenta Schreiber (2013a) que a ciência jurídica não apresenta uma solução pronta para essas colisões, visto que não há norma específica sobre qual direito deve preponderar, afinal, ambos possuem proteção com igual intensidade e hierarquia.

Sugere Steinmetz (2001) que a decisão normativa final, judicial ou legislativa, deve buscar o imperativo da otimização e da harmonização entre os direitos colidentes, respeitando, assim, o princípio da unidade constitucional e da concordância prática; no entanto, alerta que, embora fundamental, a simples interpretação constitucional não é suficiente, e sugere a aplicação da ponderação como proposta para solução do conflito.

Originária na Alemanha, a aplicação da técnica de ponderação consiste em "adotar uma decisão de preferência entre os direitos ou bens em conflito; o método que determinará qual direito ou bem, e em que medida, prevalecerá, solucionando a colisão" (STEINMETZ, 2001, p. 140). Por óbvio, não se realiza uma ponderação na qual se atribui precedência à norma de maior hierarquia ou significado, mas sim contemplam-se as peculiaridades de cada caso, valendo-se da concordância prática, permitindo assim, que cada norma jurídica em colisão ganhe realidade (MENDES et al., 2016).

Para Canotilho et al. (2014), a utilização da técnica da ponderação, de normas, bens, ou valores, se manifesta através de concessões recíprocas, visando a preservar ao máximo cada um dos direitos em jogo, para posteriormente proceder-se à escolha do direito que prevalecerá.

No caso específico de veiculação de imagens de vítimas de acidentes de trânsito, a jurisprudência vem aplicando o método da ponderação, tendo como principal pressuposto para fundamentar a decisão a relevância pública daquela informação:

APELAÇÃO CÍVEL. Responsabilidade civil. Exercício de liberdade de informação. Direito à imagem. Reportagem jornalística. Fotografia publicada em jornal e vídeo divulgado na internet sobre acidente de trânsito e demora no atendimento pela Samu. Compreensão dos direitos constitucionalmente assegurados. Interesse da coletividade. Matéria jornalística de cunho eminentemente informativo. Danos extrapatrimoniais não configurados - responsabilidade civil e o exercício da liberdade de informação. A imagem, como direito fundamental do cidadão $\left(\operatorname{art} .5^{\circ}, X, C F\right)$, possui um conjunto de limites legais e constitucionais que devem ser examinados em cada caso concreto.Aliberdadedeinformaçãotambémpossuiexpressaprevisão constitucional (art. 220, CF) sujeitando-se aos limites juridicamente admitidos. Um dos primeiros aspectos a ser verificado consiste na veracidade da notícia jornalística. $\mathrm{O}$ abuso de direito constituise no segundo aspecto que deverá ser investigado, nos termos do artigo 187 do Código Civil. Em relação aos limites externos, adota- 
se o critério da posição preferencial à dimensão coletiva do direito de informar. Necessidade de ponderar o exercício da liberdade de informar com outros direitos fundamentais. - REPORTAGEM JORNALÍSTICA - AUSENTE VIOLAÇÃO A DIREITO À IMAGEM - Caso em que se verifica tanto das fotografias, quanto do texto transcrito, que o objetivo primordial da reportagem veiculada no jornal e no sítio eletrônico do demandado foi noticiar os fatos ocorridos, diante do interesse público para a população da cidade de Cachoeira do Sul, por envolver não apenas o acidente de trânsito sofrido pelo autor e sua esposa, mas o aumento do número de acidentes no trânsito daquele município, bem como a demora no serviço de atendimento de urgência prestado pela SAMU, do que emerge da matéria jornalística examinada seu cunho informativo preponderante. Caso concreto em que não se constata abuso no exercício da liberdade de informação. Ação improcedente. Sentença mantida. Apelo desprovido. (Apelação Cível nº 70049712060 - RS, Tribunal de Justiça do Rio Grande do Sul, Relator: Leonel Pires Ohlweiler. Julgado em 24 out. 2012). (Grifo das autoras).

Nota-se, assim, que, frequentemente, especialmente no uso indevido da imagem, têm sido utilizadas as premissas do lugar, da pessoa e da relevância públicas, legitimando que imagens captadas em locais públicos podem ser divulgadas independentemente da autorização do titular. No entanto, tais parâmetros não podem ser taxativos e devem ser revistos, conforme dispõe Schreiber (2013a). Não se trata de exigir autorização prévia em todos os casos de divulgação, visto que inviável, mas sim proceder ao seu uso ético. Também, para o autor, o critério do local público está desatualizado, visto que atualmente ampliaram-se as ferramentas para captação de imagens, diferentemente do passado, que exigia numerosos equipamentos fotográficos.

A solução que se busca através da ponderação não está baseada em uma hierarquização abstrata, mas, sim, em um sopesamento que considera as circunstâncias fáticas. É justamente por isso que ora ela possibilita proteção aos direitos de personalidade e ora à liberdade de informação. Ainda que este método não ofereça uma resposta certeira para as colisões de direitos fundamentais, a ponderação propicia uma sinalização ao intérprete, permitindo que este construa de maneira progressiva parâmetros próprios que possam guiar sua decisão (SCHREIBER, 2013b).

Diante da discussão travada, analisando-se o trabalho legislativo e as decisões judiciais, percebe-se que ainda não se possui uma solução nítida para o uso de imagens frente à liberdade de informação ou expressão por meio de jornais, redes sociais como Facebook e outras, rádios, blogs, aplicativos como o WhatsApp e outros. Dessa maneira, o que resta é promover um diálogo permanente entre Direito e Comunicação, buscando manter-se atualizado para compreender as novas tecnologias, conscientizando-se dos riscos que o seu mau uso pode acarretar. 
Sobre a possibilidade de reparação às vítimas, valendo-se das palavras de Dantas, Cavalieri Filho (2007) afirma que o objetivo principal da ordem jurídica é proteger o lícito e reprimir o ilícito. Dessa forma, a violação de um dever jurídico gera um ato ilícito, que pode acarretar dano a outrem, surgindo, assim, a necessidade de reparar tal dano. É, então, nessa perspectiva que se desenvolve a ideia de responsabilidade civil, com base no Código Civil, Constituição Federal e Súmulas do Superior Tribunal de Justiça, dentre outros, nascendo para a vítima ou mesmo a seus familiares a possibilidade de reparação.

Com relação à exposição de imagens de vítimas de acidentes de trânsito, alguns Tribunais têm entendido que o simples uso não consentido de uma imagem já é suficiente para caracterizar a violação e assim ensejar o cabimento do dano moral:

RECURSO ESPECIAL. Ação de indenização. Dano moral. Direito à imagem. Morte em acidente automobilístico. [...] 2. Havendo violação aos direitos da personalidade, como utilização indevida de fotografia da vítima, ainda ensanguentada e em meio às ferragens de acidente automobilístico, é possível reclamar perdas e danos, sem prejuízo de outras sanções previstas em lei, conforme art. 12 do Código Civila2002. 3. Em se tratando de pessoa falecida, terá legitimação para as medidas judiciais cabíveis, o cônjuge sobrevivente, ou qualquer parente em linha reta, ou colateral, até o quarto grau, independentemente da violação à imagem ter ocorrido antes ou após a morte do tutelado (art. 22, § único, C.C.).

4. Relativamente ao direito à imagem, a obrigação da reparação decorre do próprio uso indevido do direito personalíssimo, não havendo de cogitar-se da prova da existência de prejuízo ou danos. O dano é a própria utilização indevida da imagem, não sendo necessária a demonstração do prejuízo material ou moral. Precedentes. 5. A indenização deve ser fixada em termos razoáveis, orientando-se o juiz pelos critérios sugeridos pela doutrina e jurisprudência, com razoabilidade, valendo-se de sua experiência e bom senso, atento à realidade da vida e às peculiaridades de cada caso. Impossibilidade de modificação do quantum indenizatório sob pena de realizar julgamento extra petita. Recurso especial provido. (Recurso Especial n. 1.005.278 - SE, Superior Tribunal de Justiça, Relator: Min. Luis Felipe Salomão. Julgado em 04 nov. 2010). (Grifo das autoras).

Oposto a esse entendimento, há na jurisprudência julgados no sentido de que a caracterização do dano moral está condicionada à dor, vexame, sofrimento ou humilhação:

DIREITO DE IMAGEM - Dano moral - Proteção calcada em garantia individual prevista na $\mathrm{CR}$ (art. $5^{\circ}, X$ ) - Divulgação de foto, em 
sítio eletrônico da empresa ré, não consentida de filha da autora, envolvida em acidente automobilístico com morte - Retratação de sua imagem, sendo socorrida em via pública - Proteção desta que não encontra imunidade total - Contexto da divulgação que não se reputa ofensivo à memória da vítima, ou aos seus parentes, pois apenas destinada a divulgar a ocorrência de um grave acidente - Divulgação de fatos verídicos e relevantes à sociedade Preponderância do interesse público em relação ao direito à imagem - Dano moral não caracterizado. (Apelação Cível n. 100626473.2015.8.26.0007 - SP, Tribunal de Justiça de São Paulo, Relator: Des. Galdino Toledo Júnior. Julgado em: 05 abr. 2016). (Grifo das autoras).

Como visto, é bastante diversificada entre os julgadores a possibilidade de indenização patrimonial às vítimas ou seus familiares no caso de exposição de imagens de acidentes de trânsito. Portanto, tendo em vista que o objetivo principal da reparação é compensar o ofendido pelo dano sofrido da forma mais abrangente possível, além do pagamento em dinheiro, também há a possibilidade, no caso de uso indevido da imagem de apreensão dos exemplares de revistas e jornais, a retirada de circulação de fotos ou vídeos expostos na Internet (SCHREIBER, 2014).

\section{CONCLUSÃO}

Como a informação tornou-se algo fácil de ser acessada e também compartilhada, a propagação de ideias, fatos, imagens e notícias por intermédio das redes sociais, como o Facebook, e aplicativos, como o WhatsApp, passou a fazer parte da rotina dos cidadãos e também dos veículos de comunicação. É notório que essa prática encontra amparo no direito fundamental à informação, do qual irradiam a liberdade de expressão e de informação, institutos esses que conferem a todos o direito de informar e ser informados.

Ocorre que há casos em que não há filtragem prévia do que está sendo difundido e, assim, mesmo que não intencionalmente, são divulgadas imagens e notícias que ultrapassam os limites da liberdade de informação e de expressão, que acabam invadindo a esfera reservada aos direitos de personalidade dos envolvidos. Exemplo prático disso é a exposição de imagens de vítimas de acidentes de trânsito, as quais, como se percebe, tornaram-se objeto corriqueiro de compartilhamento nas redes sociais e também em capas de jornais, televisão e outros meios de comunicação. Tal ato pode ensejar uma colisão de direitos fundamentais, traçada entre os direitos de personalidade das vítimas, que têm sua imagem exposta, em face da liberdade de expressão e de informação daqueles que compartilham tais imagens.

Tendo em vista que nenhum deles é considerado como direito absoluto, para solucionar tal conflito faz-se necessário recorrer à técnica da ponderação, que leva em consideração especialmente as circunstâncias particulares de cada 
caso concreto, o que faz gerar entendimentos jurisprudenciais diversos sobre a violação dos direitos de personalidade de vítimas de acidentes de trânsito.

Diante da análise do problema proposto para este estudo - em que circunstâncias são violados os direitos de personalidade de vítimas em acidentes de trânsito pela exposição de suas imagens? -, pode-se concluir que a hipótese inicial levantada para tal questionamento é verdadeira em parte, na medida em que, de modo geral, na teoria a exposição não autorizada de imagem acarreta violação aos direitos de personalidade. No entanto, na prática nem sempre isso ocorre, porque as decisões judiciais não são uniformes quanto ao assunto. Parte delas demonstra que para configurar lesão aos direitos de personalidade não basta a simples exposição da imagem, mas sim que ela tenha sido utilizada com finalidade sensacionalista e vexatória; ou seja, quando o foco principal da publicação tanto em jornais, redes sociais como em aplicativos não for o de informar sobre o acontecimento do acidente, mas sim valer-se da imagem com intuito meramente comercial ou sensacionalista, expondo corpos e até mesmo cadáveres mutilados, ocorre a violação dos direitos de personalidade, visto que foram ultrapassadas as barreiras da liberdade de expressão e de informação.

Essas divergências jurisprudenciais se justificam, pois nos casos de colisão de direitos fundamentais, os julgadores aplicam a técnica da ponderação, na qual são consideradas as circunstâncias práticas de cada situação, estabelecendo formas de controle do exercício desses direitos. Entretanto, ainda que no âmbito normativo e judicial não haja um posicionamento unânime sobre esses casos, é fundamental que existam avanços nas discussões quanto ao uso das redes sociais, uma vez que tanto a legislação quanto a educação/ conscientização estão aquém da dinamicidade e agilidade do mundo virtual. Precisam, portanto, somar forças e abrir o leque de estudos para abordagem dessa temática.

Os espaços de convivência formal e informal são propícios para direcionar o uso consciente e ético das tecnologias em questão. As redes sociais, se bem exploradas, podem servir como uma poderosa ferramenta de interação e mediação no processo de aprendizagem. Essa dinâmica de trabalho tende a contribuir para a criticidade e responsabilidade no momento de compartilhar conteúdos ao grande público, evitando, assim, consequências que possam atingir os direitos de personalidade e causar problemas com a justiça.

\section{REFERÊNCIAS}

ACIDENTES Fatais no RS. Diagnóstico de 2016. Detran/RS, Porto Alegre, 14 fev. 2017. Disponível em: <http://www.detran.rs.gov.br/conteudo/39078/diagnosticode-2016>. Acesso em: 10 maio 2017.

AMARAL, Francisco. Direito Civil: Introdução. 3. ed. Rio de Janeiro: Renovar, 2000. 
ANDRÉA, Fernando de. Robert Alexy: introdução crítica. Rio de Janeiro: Forense, 2013.

BITTAR, Carlos A. Os direitos da personalidade. 8. ed. rev. e atual. por Eduardo C. B. Bittar. São Paulo: Saraiva, 2015.

BRASIL. Lei n. 5.250, de 09 de fevereiro de 1967. Lei de Imprensa. Disponível em: <http://www.planalto.gov.br/ccivil_03/leis/L5250.htm>. Acesso em: 17 maio 2017.

BRASIL. Constituição (1988). Constituição da República Federativa do

Brasil. Disponível em:< http://www.planalto.gov.br/ccivil_03/constituicao/ constituicaocompilado.htm>. Acesso em: 4 maio 2017.

BRASIL. Lei n. 10.406, de 10 de janeiro de 2002. Código Civil. Disponível em: <http:/ / www.planalto.gov.br/ccivil_03/leis/2002/L10406compilada.htm>. Acesso em: 23 abr. 2017.

BRASIL. Projeto de Lei n. 5.012/2013. Dá nova redação ao art. 20 do Código Civil. Disponível em:< http:/ / www.lexml.gov.br/urn/urn:lex:br: camara.deputados: projeto.lei;pl:2013-02-21;5012>. Acesso em: 16 maio 2017.

BRASIL. Lei n. 12.695, de 23 de abril de 2014. Marco Civil da Internet. Disponível em: <http:/ / www.planalto.gov.br/ccivil_03/_ato2011-2014/2014/lei/112965.htm>. Acesso em: 17 maio 2017.

BRASIL. Supremo Tribunal Federal. Arguição de Descumprimento de Preceito Fundamental - ADPF n. 130. Arguido: PDT. Arguente: Presidente da República. Relator: Des. Rel. Min. Carlos Brito. Distrito Federal, 30 abr. 2009. Disponível em: $<$ http://redir.stf.jus.br/paginadorpub/paginador.jsp?docTP=AC\&docID=605411>. Acesso em: 07 out. 2016.

BRASIL. Supremo Tribunal Federal. Recurso Extraordinário n ${ }^{\circ}$ 511.961-SP. Recorrente: SERTESP. Recorrido: União. Relator: Min. Gilmar Mendes. Distrito Federal, 17 jun. 2009. Disponível em: <http:/ / redir.stf.jus.br/paginadorpub/paginador. jsp?docTP=AC\&docID $=605643>$. Acesso em: 07 out. 2016

BRASIL. Superior Tribunal de Justiça. Recurso Especial n. 1.005.278 - SE. Recorrente: J. F. C. de Melo. Recorrido: CINFO-Central de Informações Comerciais. Distrito Federal, 04 nov. 2010. Disponível em: http:/ / stj.jusbrasil.com.br/jurisprudencia/17380430/ recurso-especial-resp-1005278-se-2007-0264631-0/inteiro-teor-17635397. Acesso em: 25 out. 2016.

CAVALIERI FILHO, Sérgio. Programa de Responsabilidade Civil. 12. ed. São Paulo: Atlas, 2007.

CANOTILHO, J. J. Gomes et al. Comentários à Constituição do Brasil. São Paulo: Saraiva, 2014. 
COELHO, Fábio U. Curso de Direito Civil: Parte geral. 7. ed. São Paulo: Saraiva, 2014. v. 1.

DINIZ, Maria H. Curso de Direito Civil brasileiro: Teoria Geral do Direito Civil. 24. ed. São Paulo: Saraiva, 2007. v. 1.

FARIAS, Edilsom. Colisão de direitos: a honra, a intimidade, a vida privada e a imagem versus a liberdade de expressão e informação. Porto Alegre: Sergio Antônio Fabris, 1996.

. Liberdade de expressão e comunicação: teoria e proteção constitucional. São Paulo: Revista dos Tribunais, 2004.

FERREIRA, Aurélio B. de H. Novo dicionário da Língua Portuguesa. 4. ed. Curitiba: Positivo, 2009.

FIUZA, César. Direito Civil: Curso completo. 17. ed. São Paulo: Revista dos Tribunais, 2014.

GAGLIANO, Pablo S.; PAMPLONA FILHO, Rodolfo. Novo curso de Direito Civil: Parte geral. 18. ed. São Paulo: Saraiva, 2016. v. 1.

GODOY, Claudio L. B. A liberdade de imprensa e os direitos da personalidade. São Paulo: Atlas, 2001.

GONÇALVES, Carlos R. Direito Civil brasileiro: Parte geral. 14. ed. São Paulo: Saraiva, 2016. v. 1.

MARQUES, Andréa N. G. A liberdade de expressão e a colisão entre direitos fundamentais. Porto Alegre: Sérgio Antônio Fabris, 2010.

MENDES, Gilmar F. et al. Curso de Direito Constitucional. 11. ed. São Paulo: Saraiva, 2016.

MEZZAROBA, Orides; MONTEIRO, Cláudia S. Manual de metodologia da pesquisa no Direito. 6. ed. São Paulo: Saraiva, 2014.

MORAES, Alexandre de. Direito Constitucional. 32.ed. São Paulo: Atlas, 2016.

ORGANIZAÇÃO DAS NAÇÕES UNIDAS - ONU. Declaração Universal dos Direitos do Homem. 1948. Disponível em: <www.ohchr.org/EN/UDHR/Documents/ UDHR_Translations/por.pdf>. Acesso em: 20 set. 2016.

PAESANI, Liliana M. Direito e Internet: liberdade de informação, privacidade e responsabilidade civil. 2.ed. São Paulo: Atlas, 2003.

PARÁ. Tribunal de Justiça. Agravo de Instrumento n. 2008301-18631. Agravante: Estado do Pará. Agravado: Diários do Pará Ltda. Relator Des. Eliana Rita Daher 
Abufaiad. Pará, 06 abr.2009. Disponível em: <http:/ /gsa-index.tjpa.jus.br/consultas / search?q>. Acesso em: 29 maio 2016.

PEREIRA, Caio M. da S. Instituições de Direito Civil: Introdução ao Direito Civil. 29. ed. Rio de Janeiro: Forense, 2016. v. 1.

PINHEIRO, Patrícia; SLEIMAN, Cristina. Tudo que você precisa saber sobre direito digital no dia a dia. São Paulo: Saraiva, 2009.

RIO GRANDE DO SUL. Tribunal de Justiça. Apelação Cível n. 70049712060. Apelante: A. P. G. Apelado: Jornal do Povo. Relator: Des. Leonel Pires Ohlweiler. Rio Grande do Sul, 24 out. 2012. Disponível em: <http:/ / tjrs.jusbrasil.com. br/jurisprudencia/22561289/apelacao-civel-ac-70049712060-rs-tjrs/inteiroteor-110730635>. Acesso em: 15 out. 2016.

RIO GRANDE DO SUL. Tribunal de Justiça. Apelação Cível n. 7006558138. Apelante: E. R. V. Apelado: Radio Ceres. Relator: Des. Paulo Roberto Lessa Franz. Rio Grande do Sul, 30 jul. 2015. Disponível em: <http://www.tjrs.jus.br/busca/?tb=proc >. Acesso em: 16 out. 2016.

RIO GRANDE DO SUL. Tribunal de Justiça. Recurso Cível n. 71005951777.

Recorrente: V. T. L. da S. Recorrido: RBS Participações S/A. Relator: Des. Glaucia Dipp Dreher. Rio Grande do Sul, 01 abr. 2016. Disponível em: <http:/ / www.tjrs.jus. br/busca/?tb=proc $>$. Acesso em: 18 out. 2016.

RODRIGUES JÚNIOR, Álvaro. Liberdade de expressão e liberdade de informação: limites e formas de controle. Curitiba: Juruá, 2009.

SÃO PAULO. Tribunal de Justiça. Apelação Cível n. 1006264-73.2015.8.26.0007. Apelante: M. B. da C. Apelado: BPP Serviço de Fotografia e Vídeo Ltda. Relator: Galdino Toledo Júnior, 05 abr. 2016. Disponível em: < http:/ / tj-sp.jusbrasil. com.br/jurisprudencia / 339432080/apelacao-apl-10062647320158260007sp-1006264-7320158260007/inteiro-teor-339432142 >. Acesso em: 16 out. 2016.

SANTA CATARINA. Tribunal de Justiça. Apelação Cível n. 2007.053376-8. Apelante: L. T. J. de A. L. e A. L. Apelado: Empresa Jornalística O Tempo Ltda. Relator: Des. Victor Ferreira. Santa Catarina, 05 maio 2011. Disponível em: <http:/ / tj-sc.jusbrasil. com.br/ jurisprudencia/19771837/apelacao-civel-ac-533768-sc-2007053376-8/inteiroteor-19771838>. Acesso em: 13 out. 2016.

SCHREIBER, Anderson. Direito Civil e Constituição. São Paulo: Atlas, 2013a. . Direito e Mídia, São Paulo: Atlas, 2013b. . Direitos da Personalidade. São Paulo: Atlas, 2014.

SILVA, José A. da. Curso de Direito Constitucional Positivo. 29. ed. São Paulo: Malheiros, 2007. 
STEINMETZ, Wilson A. Colisão de direitos fundamentais e princípio da proporcionalidade. Porto Alegre: Livraria do Advogado, 2001.

TOMASEVICIUS FILHO, Eduardo. Marco Civil da Internet: uma lei sem conteúdo normativo. Estudos Avançados, São Paulo, v. 30, n. 86, p. 269-285, abr. 2016.

Disponível em: <http:/ / www.scielo.br/scielo.php?script=sci_arttext\&pid=S010340142016000100269\&lng=pt\&nrm=iso >. Acesso em: 17 maio 2017. 